\title{
'To Philosophize is to Learn How to Die?'
}

\section{Saitya Brata Das}

Those who apply themselves to philosophy in the proper way are doing no more nor less than to prepare themselves for the moment of dying and the state of death - Plato. ${ }^{2}$

I

$\mathrm{P}$ hilosophical thinking, as it is thinking of existence, is essentially finite thinking. This is to say that as thinking of existence, philosophical thinking is essentially also thinking of finitude. This 'also' is not the accidental relationship between existence and finitude. Rather, to think existence in its finitude, insofar as existence is finite, is to think existence in its existentiality. Philosophy that gives itself the task of thinking the relationship between existence and finitude, must in the same gesture, be concerned with its own finitude: to philosophize is not only to think the finitude of existence, but the very finitude of thinking that thinks finite existence. To philosophize is not only to philosophize the finitude of existence as such, but also in so far as philosophising itself is a task which is essentially in itself finite. To assume as the task of thinking the finitude of existence is to think the very finitude of philosophical thinking: this is the profound relationship that exists between existence and philosophy, which is that philosophizing existence and an existential philosophy are essentially finite. This is perhaps what Socrates says of philosophizing: 'to philosophize is to learn how to die.' "To philosophize is to learn how to die": this is to say, to philosophize is to learn that philosophy and existence are essentially finite. Philosophy and existence belong to finitude and gifts of finitude; therefore to philosophize is to learn how existence is this gift. To be able to learn how existence is this gift of finitude, to be able to assume this gift that makes existence essentially finite, which is to be able to assume existence at all, is to be able to die.' Learning to die' then comes to signify the ability of dying, which is in the same gesture, the ability of existing: existence, and dying at the end must be this ability, of existing and dying. Philosophizing must provide, then, the learning of this ability: to be capable of

1 This paper profits from insightful comments from an anonymous reviewer and from discussions with Professor Gèrard Bensussan, Universite Marc Bloch, Strasbourg. Thanks to both of them.

2 "Phaedo," in The Trial and Execution of Socrates, trans. by Peter George (London: The Folio Society, MCMLXXII, 1972), 103. 


\section{LEARN HOW TO DIE}

death and existence. To be capable of death is to master it, to be equal to it, to surpass or transcend it and to be immortal. There seems to be a paradox here which we must bring to thought. If to philosophize is to learn how to die, to be equal to or master death, it thereby means to be immortal, to be able not to die, to be capable of immortality; by learning to die, by learning to be capable of death, we become capable of not-dying, or of immortality. To learn to die is to learn how not to die.

Yet there may be, at the same time, another thought of finite thinking, that existence and its finitude eludes the very grasp of philosophical thinking; that it marks the very limit of what came to be determined as philosophy; that in the very attempt to think existence and finitude, philosophical thinking exhausts its resources and thus is delivered over to its own finitude. Therefore the task of philosophical thinking is finite each time, which is to say, to come to face what disavows philosophical thinking, what abandons it to its finitude. This would have then another meaning of what Socrates names as death: not the mastery of death, and not the profit of immortality, but to be abandoned to its limit, to disappear without profit and gain of immortality, to be abandoned to its finitude insofar as finitude itself eludes the mastery of philosophical thinking. To philosophize would then be the non-mastery of dying and the experience of the gift of finitude at the limit, which means, not to be able to experience finitude, not to be able to know death so as to profit from it. If 'to philosophize is to learn how to die,' this is to say in the same gesture, to philosophize is to fail death ineluctably, to fail to realize its own finitude, in not able to own its own finitude and in not to be able to master death. In philosophizing, one does not learn enough of dying, if philosophy is nothing but learning to die, for to grasp death in philosophical learning is to fail death, to lose it ineluctably, to miss it and be thrown outside of it. Therefore, philosophical thinking, in the very task of thinking finitude, remains an evasion of death and a vain consolation.

What of existence then that remains for philosophy if the un-thought of finitude marks the very finitude of philosophical thinking? Thinking that assumes for its task to think existence itself, therefore, always invariably led to ask the question concerning the very finitude of philosophy, which is the question of the non-appropriability of the condition of philosophizing itself, the non-appropriability of its own origin, as if, as it were, philosophy can not posit its own origin in its immanence, but for that reason, attracted, in its finitude, to the 'outside' of the groundless, the abgrund ground of it, which is not the negativity but groundless that exceeds all the manner grounding, thinking, positing. What is non-appropriable but ex-sistence, in its finitude, the non-posited affirmation beyond negativity and positing: such finitude, the non-posited groundless ground is the very condition of a thinking that posits, outside the negativity of the Concept, that remains excessive to being conditioned and appropriated; which is to say, with Schelling, ${ }^{3}$ the ground remains

${ }^{3}$ F. W. J. von Schelling, Philosophical Investigation into the Nature of Human Freedom, trans. by James Gutmann (La Salle, Illinois: Open Court,1992). 
separated from existence that marks the melancholy of all finite beings. In not being able to appropriate its condition, thus of its finitude, as the veil of melancholy that separates ground from existence: this finitude alone enables to have any relationship to existence at all that philosophy attempts to think, that is to learning how to die, which is also to say, to learn how to exist. 'To philosophize is to learn how to die' would then mean-not the mastery of death, but to learn that philosophizing is essentially that which has its nonappropriable condition outside it, hence its finitude and there alone is its freedom, a melancholic, abysmal freedom. Here I refer to a reading of Schelling's most beautiful treatise on human freedom where he elaborated this innermost connection between finitude and freedom, of melancholy of all finite beings and the joy of creating, so as to think anew freedom as finite and philosophy's relation to this joyous freedom. ${ }^{4}$ There alone, where finitude grants the gift of thinking lies its joy and hope, not separated from the melancholy that adheres our finite existence, but a melancholy that is transfigured into joy, into the very possibility of creating at all. Yet that demands that we are abandoned to our own finitude, that is to say, abandoned to infinite: such an experience, says Schelling (quoted by Heidegger here) Plato, is akin to death:

He who wishes to place himself in the beginning of a truly free philosophy must abandon even God. Here we say: who wishes to maintain it, he will lose it; and who gives up, he will find it. Only he has come to the ground of himself and has known the whole depth of life who has once abandoned everything, and has himself been abandoned by everything. He for whom everything disappeared and who saw himself alone with the infinite: a great step, which Plato compared to death. ${ }^{5}$

The possibility of a free beginning for philosophical thinking lies in this abandonment, being abandoned by everything and everyone, himself abandoning everything and everyone, a step of death: thus not the mastery of death, but being abandoned to the non-appropriable and to the unconditional, having to lose death while having to die, in having to miss its finitude while being delivered over to its finitude, in its incessantly being thrown over to its death and yet having to survive itself, which is to say, not being capable of death. It misses death, that is to say, it misses its condition, such is the noncondition of abandonment-for what is to philosophize but philosophize existing and dying - and yet, in missing mastering existence and dying, this alone enables philosophy to have any relationship of free beginning with existence and finitude at all. This is the profoundest ambiguity of philosophy, 111-123.

${ }^{4}$ Saitya Brata Das, "The Melancholic Name," in Journal for Cultural Research, 11:2 (2007),

5 Martin Heidegger, Schelling's Treatise on the Essence of Human Freedom, trans. by Joan Stambaugh (Athens: Ohio University Press,1985), 6-7. 


\section{LEARN HOW TO DIE}

the very ambiguity of its possibility and existence. In its inability of death, in not being able to have the relationship with death, in not looking at death directly at the face, by looking away and averting its gaze, by taking away the poison of death's bite and yet being abandoned, precisely in this way, to abandonment: this alone is the possibility of thinking death, and the only possibility for philosophy and thinking.

Rather this is the very condition of philosophy: to survive death, to escape it, or to go beyond it, to fall outside it or transcend it. Therefore philosophical thinking, that is learning to die, is at heart, but learning how to survive death and to be able to make a leap of transcendence beyond death. Socrates' rumination on philosophizing as learning to die is therefore inescapably bound up with the question of the immortality of the soul: philosophizing seems to be meaningful only to the extent that existence is not mere tarrying with death, but to transcend it so as to come back resurrected, survived, and immortal. To philosophize is in this sense is nothing but learning how to be immortal, or better, learning not to be mortal, to refuse finitude, to disavow death's poisonous breath. Philosophy, having to think finitude, having to be profited from it, having to have the relation with existence and finitude, remains disavowal of death and existence. To desire this immortality is not the mastery of death, but the very limit of philosophical thinking. Hence, existence in its finitude somehow remains unthought, unlived, im-possible for philosophical thinking insofar as philosophical thinking assumes in the dominant form of tradition as metaphysics, the prima philosophy, or at its accomplishment and closure the name Logic, discourse of pure thought that in thinking thought also claims to think existence, so that being and thought are one.

\section{II}

'To philosophize is to learn how to die': with this Plato intimates the innermost connection between philosophy and finitude, of philosophy as essentially finite thinking. Yet finitude and death remain the innermost scandal of philosophy, scandal that is not imposed in an accidental manner from outside, but (de) constitutes the very attempt to think existence philosophically, that is to say, finitely. Yet this attempt to think existence in its finitude, in that it is, the 'facticity' of existence, the facticity of existence remains dirempted from the very thinking insofar as thinking must endeavour to grasp existence, essentially, in this very facticity. To learn to exist and learn to die insofar as it is to learn to grasp existence in its finitude is to hold existence in all its facticity, as it were, existence is beheld in front of the immobility of the philosopher's empty gaze, gaze that does not waver and oscillate, that remains resolute and decisive, transfixed and transfiguring the modes of existing and dying, the vicissitudes of arriving and passing away, but itself not moved by what is gazed, resolute not to mourn what is lost without return and what is lapsed beyond the recuperative labour of memory. Therefore philosophical thinking has this innermost relationship with what Plato calls anamnesis: transfixation and 
transfiguration of existence and accomplishment of existence through this transfiguring work of anamnesis. Memory, the labour of transfiguration of existence, is thus nothing but certain accomplishment, philosophically, of existence. 'Learning how to die' is learning how to accomplish existence, of one's own existence, philosophically: it is as if to say that existence is that which is to be accomplished, in a manner that existing finitely one can appropriate one's own existence, make it one's ownmost reality and possibility, at its very limit, at the very abyss of dizzying height, even to the point of being shipwrecked and to the point of absolute impossibility of this very existence. From Plato to Heidegger, with Hegel and even Nietzsche, philosophy has remained a certain finite thinking of appropriating finitude and death, as it were' by a necessity which is difficult to bring to articulation, to disavow certain inconsolable mourning of an infinite finitude, of an endless dying, of a non-appropriable loss otherwise than being or negativity of nothing, otherwise than even nothingness which Heidegger tries to think more primordially than negativity of certain dialectical-speculative onto-theo-logy. ${ }^{6}$ Dasein must appropriate his own death, which is in each singular case his proper: his nothingness, beyond the negativity of the Concept (Hegelian Concept of the concept, for example), belongs to his innermost being that is his as such as the very gift: Dasein is attuned (Stimmung) to this nothingness in anxiety' as it were anticipating what is his utter impossibility to be 'to be,' insofar as Dasein is in each case of existing ex-sists ex-tatically in its way to be. ${ }^{7}$ That Dasein always exsists ex-tatically in its way to be, that means, Dasein is this non-closure of ecstatic futurity, its possibility is always in any ecstatic temporality an anticipative impossibility of no-longer being able be its way to be. Is not even here finitude, as ex-tatic temporality of its way to be, insofar as it is anticipatedand Dasein anticipates it in its being-ahead of itself in each case-finitude remains the scandal of philosophy, philosophy's vain consolation, its vain attempts to remove the poisonous bite of death. Already in Plato's Socrates, this scandal is announced in the philosopher's attempt to come to terms with his own death by asking the mourned women to be driven away: with this disavowal of mourning - and also one must not forget that tragic poets do not have a place in the Republic - a certain metaphysical determination of politics is announced. Elsewhere in another place, I attempt to bring out the innermost connection of this metaphysical determination of politics, mourning, and finitude. ${ }^{8}$

How does this dominant determination of politics, in its innermost relationship with finitude and death, inhabit secretly even in Heidegger's Dasein? To be able to appropriate one's own death, for each one dies his death:

6 Martin Heidegger, "What is Metaphysics," in Pathmarks, ed. by William McNeill (Cambridge: Cambridge University Press, 1998), 82-96.

7 Martin Heidegger, Being and Time, trans. by John Macquarrie and Edward Robinson (New York: Harper \& Row, 1962), 274-311.

8 See Saitya Brata Das, Finitude, unpublished postdoctoral manuscript in UFR Philosophie (Strasbourg: Universite Marc Bloch, Strasbourg, 2007). 


\section{LEARN HOW TO DIE}

if that is to be resolute' to be decisive in stern decision to be authentic, which means not to tarry along in the state of fallenness, this implies to be resolute not to mourn one's own death, to refuse the impossibility that does not give the very possibility of being, to refuse to die without consolation and profit of meaning - not in the name of immortality of the soul nor in the name of the eternity of the Concept that happens eternally (which as Schelling ironically says of Hegel, happening that does not happen at all but happens only in thought) ${ }^{9}$ - but in finitude, nay, as finite, out of its ecstatic groundlessness and nothingness. The consolation of death and refusal of mourning neither lie in the promise of immortality nor in the negativity of the Concept, but in exsisting itself as finite. With Heidegger the finitude of Dasein is its very consolation: such is the immanence of Dasein in the imminence of 'no more able to be,' though Dasein ex-sists ex-tatically insofar as it is its transcendence in each case, and there is its care, not is its concern and solicitude which it has for entities other than Dasein and entities which are other Daseins but with whom Dasein exists proximally in everyday inauthentic manner. To care for Dasein is to care for his own finitude in authentic manner, to exist in its ownmost possibility to die his own death: this means, care is care not to mourn for one's own death and not to mourn others' death, that means not to die others' death-for anyway one does not die other's death-for to mourn others' death' and also one's, is to exist in-authentically in the falling state of Dasein, the inauthenticity that lies in refusing death of one's own, in refusing one's own, very own finitude, to refuse to accomplish one's own appropriate existence and appropriate death whose very possibility is its impossibility to be anymore. To refuse what alone is the absolute possibility in its lone absolute impossibility, to disavow what is alone the possibility of accomplishing one's own death and existence is to be irresolute, to be indecisive, to succumb to the vacillating, ambiguous, inauthentic falling, and not to be stern in the face of the inconsolable mourning. 'To learn to die' is, whether in Plato or Heidegger, is to learn not to mourn: irresolute and indecisive beings, such as women are thought to be (in Platonic or rather in Socratic Metaphysics, for example)' fragile and fainting, do not know enough of dying and therefore they also mourn too much2; the essential metaphysical determination of politics that is decisionist, resolute and stern in the face of finitude and mourning which intimates Platonic metaphysics, also intimates, inhabits, determines the innermost essence of the very Heideggerian destruction of that very metaphysics. 'To learn to die' is to, what Hegel says of death, look death face to face and to be able to "tarry" with it: such is the metaphysics of death that in Hegel's case, that converts even non-being into being, is the very labor and accomplishment of this conversion. ${ }^{10}$ Even here death remains the

9 F. W.J. von Schelling, On the History of Modern Philosophy, trans. by Andrew Bowie (Cambridge: Cambridge University Press, 1994), 134-160.

2 It would have been interesting here to articulate the question of mourning and death in relation to women in Plato's metaphysical determination of politics, a question that has to be left here unaddressed due to lack of space.

10 G. W. F. Hegel, Phenomenology of Spirit trans. by A. V. Miller (Delhi: Motilal Benarasidass, 1998), 19. 
accomplishment, the resoluteness in the face of the negativity, to 'tarry with it' so that death does not take away anything without return of a profit: this sternness, this resolute philosophical heroism gives a certain tragic resonance to philosophical thinking, that finds speculative-dialectical articulation in Hegel. Is it not the same tragic heroism, despite Heidegger's step back from Hegelian onto-theo-logical metaphysics of labor and its negativity, of Subject and the vicissitudes of its dialectical Aufhebung, remains the intimation of Heidegger's being-towards-his-death, though this death would not be thought as Concept but that Dasein ex-tatically anticipates? 'To learn to die' as 'not to die an improper death, an inauthentic death'-in each case: Socrates,' Hegel's, Heidegger's-which is, not to mourn, for to mourn is improper to the proper, resolute, authentic death; or, to mourn is to mourn a death that is improper, inauthentic. If Socrates wanted the mourned women to be driven away, it is not only because mourning is excessive, which philosophical discourse of measurement and justice (insofar as justice measures and measurement is just) demands to sober up, but that mourning is really inappropriate and improper to the decorum that befits philosophical death. 'To philosophize is to learn how to die' is in each case, thus, is a question of conduct, which may not be prescriptive in some 'objective codes': there is a mode of dying that is proper and authentic and the other is not; there is a mode of dying that is appropriate because it appropriates death itself, there is a dying that is falling and inappropriate. There is also a language, a discourse appropriate to each mode of dying: resolute, stubborn silence of the heroic-tragic man is the appropriate language (beyond language) of his in the face of the utter impossibility of his being whose very silence is his triumph in the face of his annibilation, the final laughter at the summit of existence resounding the dirsying height looking down to the yawning abyss. To refuse to speak, this reticence in the face of his death: this speechlessness is the very proper to tragic-heroic man whose stubborn speechlessness alone is his triumph, that is, not to mourn and thus not to be taken away his death from himself, though he is taken away by death. This stubborn speechlessness, this resolute silence and decisive relation to one's own finitude: this metaphysics of the tragic intimates the innermost essence of Heidegger's tragic thinking of finitude. 'To learn how to die' is also to learn how to speak, tragically, that means, how to be silent and to be stubborn in that: this tragic-heroic determination of metaphysics intimates Dasein in the face of his ecstatic finitude; this is the very transport and ecstasy of tragic Dasein, his elevation beyond the everyday averageness of the inauthentic death of others, his sublimity in his very finitude, his final language at his own limit which is his impossibility to be. Does this not explain Heidegger's resolute, stubborn, enigmatic silence about his politics, about his great 'errancy'? It is his very politics that bestows a tragic resonance to the very innermost essence of his philosophy, which is not a question of merely accidentally joining a certain party for certain accidental period of a life-time: it also intimates the stubborn, tragic silence of a man who errs, essentially and greatly, out of his groundless freedom, and therefore unforgivably.

Is silence only the speech that properly conveys the tragic ethos of a stubborn, resolute, heroic man who decisively, at the limit, responds to his own 


\section{LEARN HOW TO DIE}

finitude that is absolutely his, his death, by defiantly refusing to speak, thereby even at his death, he defiantly affirms what is most properly his, his fate and character, for the tragic heroic being, his death must constitute at once his limit and at this limit, his very fate, his fulfilled destiny? Or there is another silence, otherwise than the defiant speechlessness of the tragic heroic man responding to his finitude resolutely, a silence otherwise than the tragic appropriation of one's own death at the limit, but rather a silence that marks the very limit of all appropriation, at the limit of language, and thereby attuned itself to the lament of a mourning? Such silence is not the pathos of a tragic heroic man of finitude, who faces alone his own impossibility and therefore alone redeems his only possibility, that is, to be impossible. To think such silence, as the lament of mourning, beyond the defiant appropriation of finitude, it is necessary to think silence and of language otherwise than the tragic heroic pathos of solitary man or of ecstatic Dasein's being-towards-his-death or the philosopher's learning to die. If language remains tied to death-as both Hegel and Heidegger, who understood death differently ${ }^{3}$, think so, that is only so far as silence- not the silence of the tragic-heroic pathos of defiant Self but rather one that is intimated with lament of mournfulness - remains the limit of language itself, that makes of a dying inappropriable for us: it is this what marks the finitude of the finite beings, finitude of the man who speaks. At the limit of language silence intimates the lament of finitude, not as the work of death, thus beyond the dialectical-speculative-tragic appropriation of death, but as the sheer unworking of language, the infinite fatigue of language, its tears and tearing unrepaired within the language, let alone in the philosophical salvation in the Concept and hence that marks the limit of the power and pain of the negative.

Does one learn how to die this death? Does philosophizing enable one to die a death which is forever inappropriable, that marks the limit of all possibility and hence beyond the decision and indecision, beyond the fate and immortality? Who learns to die and from whom?

\section{III}

'To die,' for the tragic-heroic man, is to die silently. This defiance marks even the meta-ethical ethos of Rosenzweig's tragic man insofar as this man is not mere individual or personality but Self, his very character: his fate lies in his refusal to speak and thereby breaking all bridges not only between himself and other finite beings, but even with Gods and the World. Thus in Greek Attic tragedy, especially in the works of Aeschylus, Rosenzweig finds the purer expression of this fateful silence of meta-ethical man, as contrast to the

3 Thus Heidegger, in his What is Metaphysics?, attempts to think of nothing in a more originary manner than Hegelian negativity, the later constitutive of a speculative logic: " the nothing is the origin of negation, not vice versa. If the power of the intellect in the field of inquiry into the nothing and into being is thus shattered" then the destiny of the reign of "logic" in philosophy is thereby decided. The idea of "logic" itself disintegrates into turbulence of a more originary questioning." Heidegger, Pathmarks, 92. 
non-tragic Asians (India and China). ${ }^{4}$ The heroic ethos of the tragic man belongs properly to the meta-ethos: beyond the ethos of individuality and personality, the meta-ethical man' by defiance of his free will' elevates himself above his connection with his mere pro-geniture that links him with others and with the universality of genus. That is why the birth and death of the Self or of Character of the tragic man is not synonymous with the birth and death of individuals and personality; rather otherwise, the birth of the Self, this defiant Self of the tragic man is precisely the death of the individual and personality, death that assaults him first in disguise as Eros and than as thanatos without disguise. The birth of the defiant Self, its only possibility to be lies in this most abysmal death that assaults him, at the very limit of his language and his being: from then on, this deimon silently accompanies him, as it accompanies Socrates, beyond the moral universal order of ethics shared by others; from then on his death alone is his "sovereign event," 11 it alone constitutes his fate and therein he responds fatefully with his decisive, stern, resolute silence, in his refusing to speak to Gods and others and the World, in refusing to communicate with the universal moral order where there are only personalities. Yet this death, death of the absolutely solitary man, cut off from Gods and mortals alike to which the defiant Self of tragic man responds by refusing to speak, this death alone constitutes absolutely his Self as such, this silence alone constitutes his language as such which he responds fatefully, resolutely. Therefore silence alone is proper to the tragic hero of the meta-ethical man: that marks his sublimity and elevation, his fate and singularity, his very 'selfication.' Thus Rosenzweig says,

For that is the criterion of the self, the seal, the seal of its greatness as well as the stigma of its weakness: it keeps silent. The tragic hero has only one language which completely corresponds to him: precisely keeping silent. It has thus from the beginning. The tragedy casts itself in the artistic form of drama just in order to be able to represent speechlessness...by keeping silent' the hero breaks down the bridges which connect him with God

4 I am profited from a discussion with Gèrard Bensussan who rightly pointed out to me that for Rosenzweig the silent defiance of the mythic-tragic hero is not the end or finality' but constitutes only the beginning' the point of departure towards what demands going beyond the tragic-mythic world of the Greek individuality. Having agreed with him, I am interested to see that the textual logic that governs Rosenzweig's The Star of Redemption precisely enables Rosenzweig to contrast the Tragic-mythic world of Greek individuality with the un-mythic Asians (Indian and Chinese) with the clear privilege given to the tragic world of Greek individuality. Thus towards the end of The Star of Redemption not only Indian and Chinese religions are left behind as un-mythic, but even Islam as world religion is portrayed in not so favourable light. Christianity and Jewish religions alone have remained destinal religions, surpassing the un-mythic Asian and the Islam religion. No doubt a Hegelian historical systematic still governs Rosenzweig's textual logic, which otherwise is a polemic against Hegelian Idealist philosophy.

11 Franz Rosenzweig, The Star of Redemption, trans. by William W. Hallo (London: Routledge and Kegan Paul, 1971), 76-77. 


\section{LEARN HOW TO DIE}

and the world, and elevates himself out of the fields of personality' delimiting itself and individualizing itself from others in speech, into the icy solitude of self. ${ }^{12}$

And,

The hero as such as to succumb only because his demise entitles him to the supreme "heroization," to wit, the most closed-off "selfication" of his self. He yearns for this solitude of demise' because there is no greater solitude than this. Accordingly the hero does not actually die after all. Death only cuts him off, as it were, from the temporal features of individuality. Character transmitted into heroic self is immortal. For him, eternity of just good enough to echo his silence. ${ }^{13}$

This heroic, defiant, tragic pathos, this resolute refusal to speak even unto death that entitles one's own death to be one's own, this jargon of elevation of authenticity, of sublimity of heroic sacrifice, this selfication in its very demise, this stubborn holding onto one's death of the solitary sky and earth: this pathos marks the very ethos of a certain dominant metaphysics of death. Death at the end must be able to give each one- to the philosopher learning to die, to Dasein in his being-towards-his-death, to the Historical becoming of Spirit in its negativity, to the tragic, meta-ethic man of silencehis own death, that death must be one's own, that death must at the end be one's own possibility of immortality and or his authentic being, death that would be appropriate and appropriable, a capability and possibility, death that would at the end give one his very Self or being in relation to which the stubborn silence refusing to share his elevation and solitude with others would be maintained: this stern language has remained the dominant metaphysics of death. ${ }^{5}$ And this metaphysics of death, in various forms and shapes, determines itself on a certain dominant thinking of tragedy and tragic: the questions of sacrifice and community, language and being, temporality and

12 Ibid., 77.

13 Ibid., 78-79.

5 If I have here pointed out that each of these thinkers-Heidegger, Rosenzweig's mythic hero and Nietzsche- - has a certain thinking or valorisation of a tragic heroic death in its intimate connection with language, this is not to level off, or to put into the same basket Heidegger's tragic acceptance of Nazi Ideology with Rosenzweig's messianic affirmation. These two have different levels of discourse; or rather they have two different discursive histories. What I am attempting here is only to point out that death is in each case with these thinkers, that means differently and singularly, is understood as 'possibility': this 'possibility' has a certain discursivemetaphysical history, the articulation of which is a different thing than their political allegiance. Thus it ought not to be concluded that because both Heidegger's Dasein and Rosenzweig's mythic-heroic man assert resolutely a tragic death - that thereby one's tragic assertion of Nazi Ideology is immediately juxtaposed, or levelled off with the other's messianic affirmation of a time beyond violence. 
finitude-all these questions that are at stake here, are already determined on the basis of this tragic heroic ethos, ethos that intimate the Greek tragic heroes to the philosophical heroism of 'learning to die.'

\section{IV}

When for a finite being his own existence becomes for the first time the question of his fate? When he for the first time asks 'who am 'I'? These two questions have an innermost connection in that the question of fate is inwardly bound up with the question of Self, or character: so one asks, when for the finite being, his Self becomes, that alone, the sovereign fate, "the sovereign event" of his existence? When a finite being comes to face with the most sovereign necessity, the most ineluctable destiny that his Self must become his fate, and that alone, and that his fate lies in that he must be Self? As if the very notion of 'fate' is bound up, in an ineluctable manner, with the 'selfication' of self; where, then, this necessity arise, the necessity of 'selfhood' for the finite being, for the necessity of 'self-hood' seems meaningful only for finite being, insofar as one is finite? Only for the finite being the necessity seems to arise for 'selfhood,' for 'selfication' and his 'selfication' as his fate, his destiny, his necessity; his fate, his Self is, thus, bound up with his finitude, the utter groundlessness of his being, the abyss of his nothingness.

Therefore the question of fate and character, the selfhood of the Self lies in this: when one confronts death, when one looks into the abyss, the utter impossibility of his Self, the groundlessness of his being or existing and then and there the necessity arises, in the face of death that has become one's "sovereign event", to constitute oneself to be the necessity, the stern fate and resolute Self; the most inescapable demand, then, arises to convert even the nothingness of one's abysmal existence into the most defiant Self and resolute character. Therefore only someone who has character is said to have fate or to be fateful; in other words, only someone who is Self has his fate; it is the fate of the one who has seen death in face and, as Hegel says, stays "tarrying with it"14 and not only that, he converts his groundlessness into the very ground of his self, into the very condition and possibility of his being. The birth of Self, the condition of "Selfhood" of Self, thus, lies when the abyss of death reveals itself and the finite human being looks with unspeakable horror at his utter impossibility: his every comfort in the world, his faith in the solidity and subsistence of existence, his trust in the arrangement of human destiny and its historicity is at once shattered and lost. This impossible experience of death makes the finite being attuned to a certain fundamental attunement of melancholia, a certain impossibility of dying as if one is already always dead and that his death has already been taken away from him. This sadness oppresses,

${ }^{14}$ Hegel, Phenomenology of the Spirit (1988), 19. 


\section{LEARN HOW TO DIE}

Hegel says, even the animals: so the animal or the bird of prey does not even wait looking at his victim; he jumps into it and annihilates it. 15

This sadness separates him, thenceforth, from the world in which he exists with others as individual and also cuts him off from God: from then on silently he carries his own death, or rather his death carries him in a sovereign manner, alone in absolute solitude, while he is still with others, speaks to them in the manner everyone speaks, suffers similar predicaments and pain, strives for same things like others and entertains himself with the same pleasures. Yet something, that terrible thing that happened to him in his absolute solitude, which he henceforth is carried silently like a silent companion, this constitutes his absolute secret: he speaks everything thenceforth to everyone, yet the essential thing, the only sovereign thing for him, that alone remains unspoken; this secret will then separate him from everyone and everything else in the world and make him, as separate and different from others, his 'Self,' his distinct fate, his solitary sovereign destiny. Something remains incommunicable and uncommunicated thenceforth: this secret is his self, and since this is his "sovereign event", that must be for him his 'fate,' to which he can only respond fatefully. From that fateful moment onwards, when his Self is born, precisely when he died, he responds to everything in the world which arise and pass away in a mortal manner, in a fateful manner: as if in a certain manner he is always already dead, as if death is not like what it is for ordinary conception, namely, a datable event at the end of life, but rather for him at any moment of his existing he is already always dead as possible; as if then onwards the "empirical", datable event no longer matters anymore as final annihilation. He responds to his death, thenceforth, no more like "everyday","inauthentic manner" for everyday Dasein does not have fate or destiny (we can understand here why for a tragic philosopher like Heidegger "destiny" is such a dear word), he responds fatefully to his ecstatic destiny, beyond averageleveling of "datable" death, for "datable" death (which is investigated by regional ontologies, and thus in a manner of entities Vorbandenheit) is precisely for Heidegger non-fateful, inauthentic death. Or like Hegel, he looks at life with an empty gaze of the philosopher: existence fleets by in front of it, but his gaze does not waver, for any wavering anyway does not bring anything new. Or he makes his own self the defiant response to his own death, making it the occasion for the very possibility of his self, albeit a vain triumph and impossible assertion, for it takes away from him his very possibility. This is the response of the tragic man of meta-ethic, the heroic ethos of defiance: his noncommunication and silence, his secret and solitude, his selfhood and his fate, his character and his death. There seems sometbing like tragic about the philosopher's empty gaze and something philosophical about the tragic defiance: they are responses to the abyss of being, the groundlessness of existence, the finitude of all finite beings; they are responses to death which haunts the philosophers and tragic hero alike and this response in turn constitutes the very dominant destiny of western metaphysics.

${ }^{15}$ G. W. F. Hegel, Phenomenology of Spirit trans. by A. V. Miller (Oxford: Clarendon Press, 1979), 65. 
From the tragic, heroic, defiant response to nothingness and to death, there arises the tragic, heroic, defiant metaphysics. A tragic, heroic, defiant learning to die.

\section{V}

Can one die one's own death? Can one speak one's own speech, one's own language? Franz Rosenzweig's The Star of Redemption begins with the articulation of the innermost connection of philosophical death and philosophical language. If in the innermost manner, philosophical death is tied to the philosophical language that seeks to restore what is lost as existence in its immediate, sensuous finiteness, as if learning to die one's own death, one also learns to speak one's own language, no longer merely as the finite Self, but as what Rosenzweig says, "the Cognition of the All"; it is philosophy's vain attempt to retrieve, to recuperate, to resurrect-not the decaying as decaying, but as the transfigured presence-in language of what the earth can not claim, what is rescued from the unconscious elements of the earth. ${ }^{16}$ Thus in his Lectures on the Pbilosopby of Religion, Hegel speaks of the nullity of a death that is nothing but already implicitly negative, and also nullity of mourning and fear that the man of the religion of nature bewails at this null, vain finitude:

The natural, simple self-emancipation of the finite from its finiteness is death. This is the renunciation of the finite' and here what the natural life is itself implicitly is made explicit really and actually. The sensuous life of what is individual or particular has its end in death. Particular experiences or sensations as particular are transient; one supplants the other, one impulse or other drives away the another.... In death the finite is shown to be annulled and absorbed. But death is only abstract negation of what is implicitly negative; it is itself a nullity, it is revealed a nullity. But explicit nullity is at the same time nullity which has been done away with, and is the return to the positive. Here cessation, liberated from finiteness, comes in. Death does not present itself to consciousness as this emancipation from finiteness, but this higher view of death is found in thought, and indeed even in popular conceptions, in so far as thought is active in them. ${ }^{17}$

What of the death philosophy attempts to think then, if not the death that has lost its poisonous sting, in the philosophical language in which the mortal cry of the fear of death is not heard, where the abyss of the grave is not

${ }^{16}$ See Hegel, Phenomenology of the Spirit (1988).

17 G. W. F. Hegel, Lectures on the Philosophy of Religion, Vol. I, trans. by E. B. Speirs (London: Routledge and Kegan Paul, 1962), 182. 


\section{LEARN HOW TO DIE}

revealed? Finally, it seems that philosophy is neither capable of consoling us from death, death with its sting, nor is it capable of language; philosophy has remained thus without death and without language, or rather it thinks of a death which nobody dies, and speaks a language which nobody speaks; by thinking death only as negative, as "nought" of thinking itself, and by subordinating language to thinking, philosophy remains without language and a vain attempt to take from us the fear of death. By depriving the singular from the universal, philosophy which is "cognition of the All" vainly attempts to console us by presenting a death made harmless by depriving its poison, for only singular dies, and only the singular speaks, as if by a necessity within philosophical discourse, each time the demand of thinking death arises so as to be profited from it, the demand not to drink its poison, demand not to die a poisonous death necessarily announces itself in advance, by a necessity to avert its gaze not to look death face to face, not to look directly at the groundless abyss of its own condition, only as "not-not" but not "it is". Thus Rosenzweig says,

For indeed, an All would not die and nothing would die in the All. Only the singular can die and everything mortal is solitary. Philosophy has to rid the world of what is singular, and this un-doing of the Aught is also the reason why it has to be idealistic. For idealism, with its denial of everything that distinguishes the singular from the All, is the tool of the philosopher's trade. With it, philosophy continues to work over the recalcitrant material until the later finally offers no more resistance to the smoke screen of the one- and- all concept. If once all were woven into this mist, death would indeed be swallowed up, if not into the eternal triumph, at least into the one and universal night of the Nought. And it is the ultimate conclusion of this doctrine that death isNought. ${ }^{18}$

Death is "nought": if to philosophize is learn that death is "nought", the nullity of mourning for a death that is nullity itself, this nullity itself remains inconsolable for the singular and solitary, for the one who is mortal and abandoned. Hence Socrates' vain attempts to console the mourned women at his death: between Socrates' relation to his own death and the women's relation to Socrates' death, there remained unaddressed the place of mourning, this caesura in the philosophical discourse, caesura that marks the limit of this philosophical lesson of learning how to die.

\footnotetext{
${ }^{18}$ Rosenzweig, op cit., 4.
} 


\section{VI}

"Die at the right time": this is also the teaching of Zarathustra. ${ }^{19}$ Death must not be a creeping thief but the consummation and squandering of the victorious soul. Is not the most abysmal thought of eternal return, the abysmal thought of the death of God is no other than the thought of dying itself? Then "to die" is essentially a task, the most abysmal task which only the squandering, great soul can accomplish, and which marks the very consummation of his tragic adventure: it is the task of the one who throws the golden ball and consummates his existence like the timely fruit, it is the task of the one who transforms himself from camel in the desert to the lion and then to the child, who walks over the bridge of man-for "man is bridge and not his own end"20_-so that this squandering, autumnal hero is also the rope walker, rope that hangs over the abyss of time. Death must not be the objection of him who walks over his own abyss but the very consummation of his tragic existence, for in dying rightly he also overcomes the revenge of time with a tragic laughter: such is the meaning of the eternal return as the thought of death, for the eternal return redeems time, time that comes creeping and closes itself, arises and falls itself in generating and passing, the labour of the historical, homogenous, empty time. By freeing oneself from the labour of the empty, historical, homogenous time-time that comes creeping like the thiefis to free oneself for death that consummates the great squandering, victorious soul that while consummating, also redeems it: the thought of the eternal return, as the thought of death, is thus the thought of the redemption of historical, homogenous, empty time. Yet this almost messianic sounding thought of eternal return - the contemporary philosophers like Gèrard Bensussan ${ }^{21}$ brings to articulation the innermost affinity, if not identity, of the thought of eternal return with the thought of the messianic - is also intimated by the tragic resonance of the heroic ethos, the very ethos that Nietzsche's thought of eternal return otherwise puts into question, the ethos of sacrifice on the basis of which from Socrates' death to Zarathustra's thought of death the very understanding of community and language is determined, the ethos on the basis of which certain metaphysics of sovereignty and Subject is determined, the ethos for which death has remained a 'possibility' and mastery of a 'sovereign event'. Nay, it is the very source of sovereignty itself, the sovereignty of death. I attempt to articulate the innermost connection of this tragic heroic ethos of sacrifice, thought in relation to a certain determination of death and work, of certain determination time and history with what came to

${ }^{19}$ Friedrich Nietzsche, Thus Spoke Zarathustra, trans. by Walter Kaufmann (New York: Modern Library,1995), 71-73.

${ }^{20}$ Ibid., 15.

21 See Bensussan, Gèrard, "Has Zarathustra Any Hope?," in Nietz̧sche: Philologist, Philosopher and Cultural Critic, ed. by Franson Manjali (New Delhi: Allied Publishers, 2006), 43-50 and Le Temps Messianque: Temps Historique et Temps Vècu (Paris: Vrin, 2001). 


\section{LEARN HOW TO DIE}

thought of the questions of community and language, thus the very thought of politics and the political. 22

\section{VII}

'Learning to die' at the right time? Is it not that death is always untimely, either too late or too early for one to die and hence never to be learnt, dying that began already in a beginningless time, time that is lost never to be recuperated, it already falls outside of all positing and op-positing in the very positing and time that remains, never to be anticipated but only hoped time: does this time, time that is lapsed in the un-memorial, time that intimates us in our deepest melancholy and also the time that remains for us to hope, does this time arrive at the right time, at the appropriate and appropriable time, at a possible and anticipatable and recuperable time? Can this time be thought on the basis of death, of tragic death that has learnt to die at the right time, to die heroically that befits a resolute Dasein, or Defiant Meta-ethical tragic man, or a heroic Philosopher, or the one who throws the golden ball, who affirms chance and thus redeems the empty time? Is it not that to mourn for the lapse of time, not the once present time of accomplishment and accomplishing time of presence, but the already always untimely falling away of time and to hope a time that remains, not the anticipatable time for consummating heroic accomplishment in death, but non-anticipatable hoped time that is coming -is not such time otherwise than tragic time of heroic fulfilment, and must be thought otherwise than such an ethos and pathos of the tragic determination of death and finitude? Is not such time of mourning otherwise than, more primordial than the anticipatable time of anxiety over Dasein' own imminent death, for mourning is more primordially attuned to finitude than anxiety as the fundamental attunement of finitude? Would not the time of hope, lengthened to infinity, exceeding the closure of dialectical-speculative determination of presence and beyond the metaphysics of speculative historical time, be the time of redemption, or time that redeems time itself, which cannot be thought either as the sublated time of Concept without language or as the tragic time of speechlessness? How can such time, untimely time, time outside time be thought, time that intimates our finitude in the attunements of melancholy and hope, time of un-memorial, never-present-never-accomplished lost time and time of hope for the coming, that inexhaustible time of the remains? As if it were time itself must be released from time, not in the name of the eternity of the Concept, nor in the tragically fulfilled time for the heroic, nor the laborious time of the negativity, nor the ex-tatic finitude of 'possibility of the impossibility' of Dasein, but time that is finite each time, that is limitedtime, singular and as this trans-immanence, releases time from its own closure, as that which falls outside of itself in its very arriving, so that what arrives in the very arriving diverts as what is never posited as such in any present time and also so that time remains to arrive, since what has arrived as accomplished

22 Das, Finitude. 
time of present has not accomplished all time, has remained unfulfilled and unaccomplished' so that a time remains to come, which is very arrival itself that would not be exhausted. What has remained to come is an "advent" which is at once the very thought of releasement of time and finitude: this thought of advent and releasement is attuned to our fundamental attunement of melancholy and hope, melancholy for the un-memorial time of lapsed time and hope for the time for arriving. As such melancholy and hope are the very fundamental attunements of finitude, the attunements that mark the finitude of our finite existence: as finite beings, whose condition is never appropriable, that cannot own one's own ground, we are attuned to our finitude in melancholy and hope. We are melancholic and hopeful insofar as we are finite, that finitude is not an accidental property of our existence. Our existence is this very gift of finitude. If humans speak, it is not because man is capable of death, not because death is a possibility for man, but rather speech or language is the very gift of finitude. This gift is attuned to us and intimates us, at the very limit of language, in the lament of silence, in our mourning and melancholy, in our hope for the time to come and in the redemption of coming: they mark the very limit of our power of appropriation, the power and pain of the negative. And we must be grateful and thankful for this gift, the finite gift of language. To think finitude anew demands that the closure of this dominant edifice of metaphysics is to be disclosed and to open it to the advent of releasement. What is meant hereby 'the advent of releasement' shall only be clear when the closure of the dominant metaphysics is opened to this advent.

In taking the problematic of time and finitude as the fundamental issue, I attempt to think that the advent of releasement as an essentially fundamental ethico-political exigency of our time: a finite politics, or ethics of finitude insofar as finitude is no longer to be seen as dialectical-speculative other of infinite concept, but non-negative finitude as releasement' the releasement of the advent. ${ }^{23}$ Reading Schelling, Heidegger, and Rosenzweig, this advent of releasement - as essentially finite, and beyond the dialecticalspeculative determination of time-is elaborated as essentially an ethicopolitical task of remembrance and arriving, in its innermost connection with melancholy and hope, the fundamental attunements of finite existence. The intimation of mournfulness in language resonates, I argue, an intimate connection between the very receiving and giving of the gift and a certain melancholy. ${ }^{24}$ Yet there is also something else: there is an intimation of hope in language, an intimate connection between the very receiving and giving of the gift and a certain hope for the coming, a hope for redemption in the coming, a hope for what remains, as if in the very gift of language, we are not only intimated with a certain mournfulness, but in hope we open ourselves to the very time that remains: in speaking and in language, we do not become capable of death, but as already finite, beyond our capacity and possibility, at the limit of our appropriation, we are given over to melancholy and hope.

\footnotetext{
${ }^{23} \mathrm{Ibid}$.

${ }^{24}$ Das, "The Melancholic Name."
} 


\section{LEARN HOW TO DIE}

What is this relationship between time and language, between time and our fundamental attunements of finitude, namely, melancholy and hope, time otherwise than either tragic time or the historical time of presence or ex-tatic time of a finite Dasein? What is the relationship between dying and language, of a dying that intimates, inhabits our language with an intimation of mourning that pushes language itself to its limit, and marks the finitude and limit of our appropriation in a manner that the philosophical discourse is exposed to its own abyss which it cannot recuperate and console, as if mourning inhabits and tears asunder the philosophical discourse itself, from within itself? And finally what is the relationship between language and community, community and time, and community and death, if language and death and time be thought otherwise than on the modality of tragic sacrifice or otherwise than the metaphysics of historical subject, otherwise than the closure of dialecticalspeculative appropriation?

Who learns how to die? The one who remains? Or the one who is no longer? From whom one learns to die? The one who remains? Or the one who is no longer?

UFR de Philosophie, Université Marc Bloch, France

\section{References}

Das, Saitya Brata, "The Melancholic Name," in Journal for Cultural Research, 11:2 (2007), 111-123.

, Finitude, unpublished postdoctoral manuscript in UFR Philosophie (Strasbourg: Universite Marc Bloch, Strasbourg, 2007).

Bensussan, Gèrard, "Has Zarathustra Any Hope?," in Nietzsche: Philologist, Philosopher and Cultural Critic, ed. by Franson Manjali (New Delhi: Allied Publishers, 2006), 43- 50. 2001).

Hegel, G. W. F., Lectures on the Philosophy of Religion, Vol. I, trans. by E. B. Speirs (London: Routledge and Kegan Paul, 1962). Phenomenology of Spirit, trans. by A. V. Miller (Delhi: Motilal Benarasidass, 1998). Phenomenology of Spirit, trans. by A. V. Miller (Oxford: Clarendon Press, 1979).

Heidegger, Martin, Being and Time, trans. by John Macquarrie and Edward Robinson (New York: Harper \& Row, 1962). Schelling's Treatise on the Essence of Human Freedom, trans. by Joan Stambaugh (Athens: Ohio University Press,1985). , "What is Metaphysics," in Pathmarks, ed. by William McNeill (Cambridge: Cambridge University Press, 1998), 82-96.

Nietzsche, Friedrich, Thus Spoke Zarathustra, trans. by Walter Kaufmann (New York: Modern Library,1995). 
Plato, "Phaedo," in The Trial and Execution of Socrates, trans. by Peter George (London: The Folio Society, MCMLXXII, 1972), 91-197.

Rosenzweig, Franz, The Star of Redemption, trans. by William W. Hallo (London: Routledge and Kegan Paul, 1971).

Schelling, F. W. J. von, Philosophical Investigation into the Nature of Human Freedom, trans. by James Gutmann (La Salle, Illinois: Open Court,1992).

, On the History of Modern Philosophy, trans. by Andrew Bowie (Cambridge: Cambridge University Press, 1994). 